medRxiv preprint doi: https://doi.org/10.1101/2021.01.06.21249185; this version posted January 8, 2021. The copyright holder for this preprint (which was not certified by peer review) is the author/funder, who has granted medRxiv a license to display the preprint in perpetuity.

It is made available under a CC-BY-NC-ND 4.0 International license .

\title{
Folate (MTHFR C677T and MTRR A66G) gene polymorphisms and risk of prostate cancer: a case-control study with an updated meta-analysis
}

\author{
Upendra Yadav ${ }^{1}$, Pradeep Kumar ${ }^{1}$, Shailendra Dwivedi ${ }^{2}$, Bhupendra Pal Singh $^{3}$, Vandana Rai $^{1}{ }^{*}$ \\ ${ }^{1}$ Human Molecular Genetics Laboratory, Department of Biotechnology, \\ VBS Purvanchal University, Jaunpur (UP)- 222 003, India \\ ${ }^{2}$ Department of Biochemistry, \\ All India Institute of Medical Sciences, Gorakhpur (UP)- 273 008, India \\ ${ }^{3}$ Deprtment of Urology, \\ King George Medical University, Lucknow (UP)- 226 003, India \\ *Corresponding author: raivandana@ rediffmail.com
}

\begin{abstract}
Introduction: Methylenetetrahydrofolate reductase (MTHFR) and methionine synthase reductase (MTRR) are the key enzymes of the folate pathway, which involved in the DNA methylation. DNA methylation may affect the stability and integrity of DNA, that supposed to play a pivotal role in carcinogenesis. So, we aimed to investigate the association of MTHFR C677T and MTRR A66G gene polymorphisms with susceptibility to prostate cancer in North Indian population. We also performed meta-analyses of published literatures on these polymorphisms to evaluate their association with prostate cancer.

Methods: We genotyped MTHFR C677T and MTRR A66G gene polymorphisms in 147 prostate cancer cases and 147 healthy controls using PCR-RFLP methods. Odds ratios (ORs) with 95\% confidence intervals (CIs) were estimated for risk estimation. For meta-analysis different databases were searched and all statistical analysis were performed using Open Meta-Analyst software.

Results: The present case control study revealed that the $\mathrm{T}$ allele (OR=1.67; 95\% CI: 0.99-2.84, $\mathrm{p}=0.05)$, CT genotype $(\mathrm{OR}=1.92 ; 95 \% \mathrm{CI}: 1.06-3.48, \mathrm{p}=0.02)$, and dominant $(\mathrm{TT}+\mathrm{CT})$ model $(\mathrm{OR}=1.85 ; 95 \% \mathrm{CI}: 1.05-3.30, \mathrm{p}=0.03)$ of $M T H F R$ C677T gene polymorphism and $\mathrm{G}$ allele $(\mathrm{OR}=1.92 ; 95 \% \mathrm{CI}: 1.35-2.73, \mathrm{p}=0.0002)$ of $M T R R$ A66G gene polymorphism were significantly associated with prostate cancer susceptibility. Meta-analyses of MTHFR C677T and MTRR A66G gene polymorphisms showed no significant association between these polymorphisms and prostate cancer risk in overall or in subgroup meta-analysis stratified by ethnicity.

Conclusion: MTHFR C677T and MTRR A66G gene polymorphisms seem to play a significant role in prostate cancer susceptibility in North Indian population, while results of meta-analysis revealed no association between MTHFR C677T and MTRR A66G gene polymorphisms and prostate cancer susceptibility.
\end{abstract}

Keywords: MTHFR; MTRR; polymorphism; PCR-RFLP; meta-analysis. 
medRxiv preprint doi: https://doi.org/10.1101/2021.01.06.21249185; this version posted January 8, 2021. The copyright holder for this preprint (which was not certified by peer review) is the author/funder, who has granted medRxiv a license to display the preprint in perpetuity.

It is made available under a CC-BY-NC-ND 4.0 International license .

\section{Introduction}

Prostate cancer is a common cancer in men with an estimated 1.2 million new cases and 0.35 million deaths worldwide [1]. The incidence of prostate cancer widely varies in different populations and more common in the developed countries. In India the five year prevalence rate of prostate cancer is 8.1 [1]. Most of the cases of prostate cancer occur in men over the age of 50. Though it is a common cancer but its etiology is poorly understood. Age, ethnicity, and family history of prostate cancer are some of the risk factors. Smoking, occupational chemicals, diet, inflammation, androgens and obesity are considered as secondary risk factors [2].

There are some factors which might be responsible for the development of cancer including DNA hypo-methylation [3], uracil mis-incorporation, and DNA strand break [4]. These all events are linked with the deficiency of the folic acid. The defects in the folic acid pathway leads to the development of cancer, but the exact mechanism is not fully elucidated. Methylenetetrahydrofolate reductase (MTHFR) is an important enzyme of folate pathway that plays a crucial role in DNA synthesis and DNA methylation. Defects in this enzyme may lead to hypo-methylation of DNA that ultimately resulted in the altered genes expression. MTHFR gene is located on the chromosome 1 . A number of polymorphisms are reported in this gene but clinically most important one is MTHFR C677T. The other crucial enzyme of the folic acid pathway is methionine synthase reductase (MTRR) which activates the inactive methionine synthase (MTR) enzyme. MTRR gene is a housekeeping gene and located at chromosome 5.

The frequency of the MTHFR C677T gene polymorphism greatly varies in different population of the world. The frequency of T allele and TT genotype was reported lowest in the African population and highest in the European population [5]. In the Eastern Uttar Pradesh population the frequency of $\mathrm{T}$ allele was in the range of $4 \%$ to $14 \%$ [6-9]. Similarly, the frequency of the MTRR A66G gene polymorphism varied from population to population. The lowest frequency of $\mathrm{G}$ allele and GG genotype was reported in the South American population and highest in the Asian population [10]. In the Eastern Uttar Pradesh population the frequency of G allele was in the range of $58 \%$ to $70 \%$ [11-13].

MTHFR C677T gene polymorphism is known to be associated with predisposition for different types of cancers like- oral cancer [14], breast cancer [15,16], colorectal cancer [17,18], gastric cancer [19,20], lung cancer [21,22], pancreatic cancer [23,24], and bladder cancer [25,26]. Similarly MTRR A66G gene polymorphism is also found to be associated with various types of cancers such as- cervical cancer [27], lung cancer [28,29], meningioma [30], colorectal cancer [31,32], head and neck cancer [33], pancreatic cancer [23], and breast cancer [34].

A number of studies were conducted to check the association of MTHFR C677T gene polymorphism with the prostate cancer [35-47]. Very few studies were published, which evaluated MTRR A66G polymorphism as risk for prostate cancer [39,40,48-50]. The results of these studies were contradictory for both the selected (MTHFR C677T and MTRR A66G gene) polymorphisms. Moreover, only a single study Mandal et al. [43] was published from India, which evaluated MTHFR C677T polymorphism in prostate cancer patients, and as per our knowledge, from India no study was published so far which evaluated the role of MTRR A66G gene polymorphism in the etiology of prostate cancer. So, we designed this study to check the role of MTHFR C677T and MTRR A66G gene polymorphisms in the North Indian prostate cancer patients and we also performed meta-analyses to check the effect of these polymorphisms on the etiology of prostate cancer. 
medRxiv preprint doi: https://doi.org/10.1101/2021.01.06.21249185; this version posted January 8, 2021. The copyright holder for this preprint (which was not certified by peer review) is the author/funder, who has granted medRxiv a license to display the preprint in perpetuity. It is made available under a CC-BY-NC-ND 4.0 International license .

\section{Materials and Methods}

\subsection{Genotyping study}

\subsubsection{Sample collection}

A total of 147 prostate cancer cases (age criteria: 40-78 years) were recruited from the outpatient clinic of King George Medical University, Lucknow. In the same time frame, 147 age matched controls from Eastern Uttar Pradesh population were enrolled. Controls were health individuals without any family history and are unrelated to the patients. Informed written consent was obtained from each subjects and the ethical approval was obtained from the Institutional Ethical Committee of King George Medical University, Lucknow and Veer Bahadur Singh Purvanchal University, Jaunpur.

\subsubsection{Genomic DNA extraction}

$3 \mathrm{ml}$ blood sample was collected in EDTA coated vials from both the case and control groups. Genomic DNA was extracted by the method of Bartlett and White [51].

\subsubsection{Genotyping}

MTHFR C677T genotyping was carried out by PCR-RFLP method of Frosst et al. [52], for MTRR A66G genotyping the method of Wilson et al. [53] was adopted. Briefly, 100ng of genomic DNA was amplified in a final volume of $15 \mu \mathrm{l}$ with $4 \mathrm{pM}$ of each of forward and reverse primers, $250 \mu \mathrm{l}$ of dNTPs mix, 1X Taq DNA polymerase buffer and 1U of Taq DNA polymerase. PCR program was initial denaturation at $94^{\circ} \mathrm{C}$ for 4 minutes followed by 30 cycles of denaturation at $94^{\circ} \mathrm{C}$ for 1 minute, annealing for 1 minute (at $62^{\circ} \mathrm{C}$ for $M T H F R$ C $677 \mathrm{~T}$ and $64^{\circ} \mathrm{C}$ for MTRR A66G), extension at $72^{\circ} \mathrm{C}$ for 1 minute and a final extension at $72^{\circ} \mathrm{C}$ for 10 minutes. The amplicons (198bp) were digested with HinfI as the C677T mutation creates a restriction site for it, and resolved in a $2 \%$ agarose gel. For A66G amplicons (66bp) digestion were performed with $N d e \mathrm{I}$ and resolved in a $4 \%$ agarose gel.

\subsubsection{Statistical analysis}

Allele frequencies were calculated by the gene counting method. $\chi^{2}$ test was performed to test the Hardy-Weinberg Equilibrium (HWE). Odds ratios (OR) with 95\% confidence intervals (CI) were calculated for the comparison of allele and genotype of cases and controls. All statistical analysis was performed by OpenEpi program.

\subsection{Meta-Analysis}

\subsubsection{Searched strategy and identification of studies}

For meta-analysis PubMed, Science Direct, Springer Link and Google scholar databases were searched for the suitable articles using the combination of the keywords "MTHFR", "methylenetetrahydrofolate reductase", "C677T", "MTRR", "methionine synthase reductase", "A66G" along with "prostate cancer". The databases were searched up to $31^{\text {st }}$ June, 2020. 
medRxiv preprint doi: https://doi.org/10.1101/2021.01.06.21249185; this version posted January 8, 2021. The copyright holder for this preprint (which was not certified by peer review) is the author/funder, who has granted medRxiv a license to display the preprint in perpetuity. It is made available under a CC-BY-NC-ND 4.0 International license .

\subsubsection{Inclusion and exclusion criteria}

For a study to include in the meta-analysis, the study should: i) be original; ii) be a case-control study; and iii) be reported MTHFR C677T or MTRR A66G alleles/genotypes. Studies were excluded if they were: i) reported either only cases or controls, and ii) review, editorial etc.

\subsubsection{Data extraction}

From all the eligible studies, following information were extracted: family name of the first author, year of publication, country of study, population/ethnic group, number of alleles and/or genotypes.

\subsubsection{Statistical analysis}

Crude odds ratio (OR) along with the $95 \%$ confidence interval (CI) were used to assess the strength of the association between MTHFR C677T and MTRR A66G gene polymorphisms with the risk of prostate cancer. In the present study, we calculated five genetic models i.e. $\log$ additive, homozygote, heterozygote, dominant and recessive models. The ORs were estimated for both the fixed effect [54] and random effect [55] models. The between studies heterogeneity was tested using the Q-statistics and was quantified using the $\mathrm{I}^{2}$ statistics [56]. If $\mathrm{I}^{2}>50 \%$ then random effect model was used otherwise fixed effect model was adopted. We further stratified our results on the basis of ethnicities. For the assessment of publication biases Egger's test was used [57]. Funnel plot of standard error by $\log$ OR and funnel plot of precision by log OR were generated. All the $\mathrm{p}$ values were two tailed with a significance level at $<0.05$. All statistical analyses were performed through Open Meta-analyst program [58].

\section{Results}

For the present case-control study we collected 147 prostate cancer samples (age $=62.72 \pm 11.84$ years) and the mean prostate specific antigen was $29.61 \pm 21.41 \mathrm{ng} / \mathrm{ml}$ and same number of age matched controls (age $=62.03 \pm 10.76$ years $)$.

\subsection{Association of MTHFR C677T and MTRR A66G gene polymorphisms with prostate cancer risk}

The genotype distribution of MTHFR C677T gene polymorphism was in agreement with HardyWeinberg equilibrium (HWE) $(\mathrm{p}=0.38)$ but the genotype distribution was deviated from the HWE for the MTRR A66G gene polymorphism ( $\mathrm{p}=00001)$. For MTHFR C677T gene polymorphism, the frequency of $\mathrm{C}$ and $\mathrm{T}$ allele in cases was 0.86 and 0.14 respectively, while in controls $\mathrm{C}$ and $\mathrm{T}$ allele frequencies were 0.91 and 0.09 respectively. The CC, CT and TT genotypic frequencies in cases were $0.74,0.25$ and 0.01 respectively, and the frequencies in controls were $0.84,0.15$ and 0.01 respectively. The $\mathrm{T}$ allele of MTHFR C677T was slightly associated with the prostate cancer $(\mathrm{OR}=1.67 ; 95 \% \mathrm{CI}$ : 0.99-2.84, $\mathrm{p}=0.05)$. A significant association were also found between $\mathrm{CT}$ genotype $(\mathrm{OR}=1.92 ; 95 \% \mathrm{CI}: 1.06-3.48, \mathrm{p}=0.02)$ and dominant model $(\mathrm{OR}=1.85 ; 95 \% \mathrm{CI}: 1.05-3.30, \mathrm{p}=0.03)$ and prostate cancer $($ Table 1$)$. 
medRxiv preprint doi: https://doi.org/10.1101/2021.01.06.21249185; this version posted January 8, 2021. The copyright holder for this preprint (which was not certified by peer review) is the author/funder, who has granted medRxiv a license to display the preprint in perpetuity.

It is made available under a CC-BY-NC-ND 4.0 International license .

Table 1: Distribution and odds ration with 95\% confidence intervals for MTHFR C677T and MTRR A66G gene polymorphism

\begin{tabular}{|c|c|c|c|c|}
\hline & Allele/Genotype & Case & Control & OR (95\% CI with p-value) \\
\hline \multirow{6}{*}{ MTHFR C677T } & $\mathrm{CC}$ & 108 & 123 & 1 (Reference) \\
\hline & $\mathrm{CT}$ & 37 & 22 & $1.92(1.06-3.48), 0.02$ \\
\hline & TT & 2 & 2 & $1.14(0.12-11.09), 0.89$ \\
\hline & $\mathrm{TT}+\mathrm{CT}$ & 39 & 24 & $1.85(1.05-3.30), 0.03$ \\
\hline & $\mathrm{C}$ & 253 & 268 & 1 (Reference) \\
\hline & $\mathrm{T}$ & 41 & 26 & $1.67(0.99-2.84), 0.05$ \\
\hline \multirow{6}{*}{ MTRR A66G } & AA & 11 & 9 & 1 (Reference) \\
\hline & $\mathrm{AG}$ & 51 & 96 & $0.43(0.16-1.14), 0.07$ \\
\hline & GG & 85 & 42 & $1.66(0.61-4.36), 0.29$ \\
\hline & $\mathrm{GG}+\mathrm{AG}$ & 136 & 138 & $0.81(0.31-2.04), 0.64$ \\
\hline & A & 73 & 114 & 1 (Reference) \\
\hline & G & 221 & 180 & $1.92(1.35-2.73), 0.0002$ \\
\hline
\end{tabular}

In MTRR A66G gene polymorphism analysis, the frequency of $\mathrm{A}$ and $\mathrm{G}$ allele was 0.25 and 0.75 respectively in cases while in controls it was 0.39 and 0.61 respectively. The AA, AG and GG genotypic frequencies in cases were $0.07,0.35$ and 0.58 and in control were $0.06,0.65$ and 0.29 respectively. The $\mathrm{G}$ allele of $M T R R$ A66G gene polymorphism was significantly associated with the prostate cancer $(\mathrm{OR}=1.92 ; 95 \% \mathrm{CI}: 1.35-2.73, \mathrm{p}=0.0002)$, while no such association was found with any other genetic model (Table 1).

\subsection{Meta-analysis of MTHFR C677T gene polymorphism in prostate cancer}

For MTHFR C677T meta-analysis we found 25 studies with 12,488 cases and 13,906 controls. [35-49, 59-67, present study]. Out of 25 studies, eight studies were from Asia, 12 were carried out in Caucasians subjects and five studies were of mixed ethnicities. Insignificant association was found in the C677T gene polymorphism in all the genetics models with high heterogeneity (For allele contrast model $\mathrm{OR}_{\mathrm{Tvs} . \mathrm{C}}=0.93,95 \% \mathrm{CI}$ : $0.85-1.01, \mathrm{p}=0.12, \mathrm{I}^{2}=66.96 \%$; for codominant model $\mathrm{OR}_{\mathrm{CTvs.CC}}=0.97 ; 95 \% \mathrm{CI}$ : 0.86-1.10; $\mathrm{p}=0.70 ; \mathrm{I}^{2}=66.77 \%$; for homozygote model $\mathrm{OR}_{\mathrm{TTv} . \mathrm{CC}}=0.80 ; 95 \% \mathrm{CI}=0.67-0.97 ; \mathrm{p}=0.02 ; \mathrm{I}^{2}=57.26 \%$; for dominant model $\mathrm{OR}_{\mathrm{TT}+\mathrm{CTvs.CC}}=0.94 ; 95 \% \mathrm{CI}: 0.84-1.06 ; \mathrm{p}=0.36 ; \mathrm{I}^{2}=68.6 \% ;$ and for recessive model $\mathrm{OR}_{\mathrm{CC}+\mathrm{CTvs.TT}}=0.83 ; 95 \% \mathrm{CI}=0.70-0.98 ; \mathrm{p}=0.03 ; \mathrm{I}^{2}=53.82 \%$ ) (Figure 1 , Table 2 ).

In sub-group meta-analyses, no statistically significant association were found in any ethnic subgroup, neither in Asian population (for T vs. $\mathrm{C}: \mathrm{OR}=0.84 ; 95 \% \mathrm{CI}=0.72-1.01 ; \mathrm{p}=0.07 ; \mathrm{I}^{2}=$ $56.87 \%$; for $\mathrm{TT}+\mathrm{CT}$ vs. $\mathrm{CC}: \mathrm{OR}=0.85 ; 95 \% \mathrm{CI}=0.68-1.07 ; \mathrm{p}=0.18 ; \mathrm{I}^{2}=59.34 \%$; for $\mathrm{TT}$ vs. $\mathrm{CC}: \mathrm{OR}=0.62 ; 95 \% \mathrm{CI}=0.53-0.73 ; \mathrm{p}=<0.001 ; \mathrm{I}^{2}=0 \%$; for $\mathrm{CT}$ vs. $\mathrm{CC}: \mathrm{OR}=0.99 ; 95 \% \mathrm{CI}=$ $0.71-1.11 ; \mathrm{p}=0.32 ; \mathrm{I}^{2}=52.43 \%$; and for $\mathrm{CT}+\mathrm{CC}$ vs. $\mathrm{CC}: \mathrm{OR}=0.71 ; 95 \% \mathrm{CI}=0.62-0.83 ; \mathrm{p}=$ $<0.001 ; \mathrm{I}^{2}=0 \%$ ) nor in Caucasian population (for $\mathrm{T}$ vs. $\mathrm{C}$ : $\mathrm{OR}=0.98 ; 95 \% \mathrm{CI}=0.88-1.08 ; \mathrm{p}=$ $0.70 ; \mathrm{I}^{2}=64.28 \%$; for TT + CT vs. CC: $\mathrm{OR}=1.00 ; 95 \% \mathrm{CI}=0.87-1.15 ; \mathrm{p}=0.97 ; \mathrm{I}^{2}=66.41 \%$; for TT vs. $\mathrm{CC}: \mathrm{OR}=0.92 ; 95 \% \mathrm{CI}=0.73-1.17 ; \mathrm{p}=0.52 ; \mathrm{I}^{2}=63.51 \%$; for $\mathrm{CT}$ vs. $\mathrm{CC}: \mathrm{OR}=1.02 ; 95 \%$ $\mathrm{CI}=0.88-1.18 ; \mathrm{p}=0.77 ; \mathrm{I}^{2}=68.32 \%$; and for $\mathrm{CT}+\mathrm{CC}$ vs. $\mathrm{CC}: \mathrm{OR}=0.91 ; 95 \% \mathrm{CI}=0.72-1.15 ; \mathrm{p}=$ $0.44 ; I^{2}=66.47 \%$ ) (Table 2 ). 
medRxiv preprint doi: https://doi.org/10.1101/2021.01.06.21249185; this version posted January 8, 2021. The copyright holder for this preprint (which was not certified by peer review) is the author/funder, who has granted medRxiv a license to display the preprint in perpetuity.

It is made available under a CC-BY-NC-ND 4.0 International license .

Table 2. Summary estimates for the odds ratio (OR) of MTHFR C677T in various allele/genotype contrasts, the significance level ( $p$ value) of heterogeneity test $\left(Q\right.$ test), and the $I^{2}$ metric

\begin{tabular}{|c|c|c|c|c|c|c|}
\hline & Genetic Contrast & $\begin{array}{l}\text { Fixed effect } \\
\text { OR }(95 \% \text { CI }), p\end{array}$ & $\begin{array}{l}\text { Random effect } \\
\text { OR }(95 \% \text { CI }), p\end{array}$ & $\begin{array}{l}\text { Heterogeneity } \\
\text { p-value (Q test) }\end{array}$ & $\mathbf{I}^{2}(\%)$ & $\begin{array}{l}\text { Publication } \\
\text { Bias (p of } \\
\text { Egger's test) }\end{array}$ \\
\hline \multirow[t]{5}{*}{ All } & Allele Contrast (T vs. C) & $0.93(0.89-0.96),<0.001$ & $0.93(0.85-1.01), 0.12$ & $<0.001$ & 66.96 & 0.95 \\
\hline & Dominant (TT+CT vs. CC) & $0.93(0.88-0.98), 0.007$ & $0.94(0.84-1.06), 0.36$ & $<0.001$ & 68.6 & 0.89 \\
\hline & Homozygote (TT vs. CC) & $0.84(0.77-0.91),<0.001$ & $0.80(0.67-0.97), 0.02$ & $<0.001$ & 57.26 & 0.58 \\
\hline & Co-dominant (CT vs. CC) & $0.95(0.90-1.00), 0.07$ & $0.97(0.86-1.10), 0.70$ & $<0.001$ & 66.77 & 0.82 \\
\hline & Recessive (CC+CT vs. TT) & 0.87 (0.80-0.94), 0.001 & $0.83(0.70-0.98), 0.03$ & $<0.001$ & 53.82 & 0.52 \\
\hline \multirow[t]{5}{*}{ Asian } & Allele Contrast (T vs. C) & $0.81(0.75-0.87),<0.001$ & $0.85(0.72-1.01), 0.07$ & 0.02 & 56.87 & 0.39 \\
\hline & Dominant (TT+CT vs. CC) & $0.78(0.70-0.86),<0.001$ & 0.85 (0.68-1.07), 0.18 & 0.01 & 59.34 & 0.30 \\
\hline & Homozygote (TT vs. CC) & $0.62(0.53-0.73),<0.001$ & $0.63(0.53-0.74),<0.001$ & 0.68 & 0 & 0.68 \\
\hline & Co-dominant (CT vs. CC) & $0.82(0.73-0.92),<0.001$ & $0.89(0.71-1.11), 0.32$ & 0.04 & 52.43 & 0.31 \\
\hline & Recessive (CC+CT vs. TT) & $0.71(0.62-0.83),<0.001$ & $0.72(0.62-0.83),<0.001$ & 0.74 & 0 & 0.98 \\
\hline \multirow[t]{5}{*}{ Caucasian } & Allele Contrast ( $\mathrm{T}$ vs. C) & $0.98(0.93-1.03), 0.46$ & $0.98(0.88-1.08), 0.70$ & 0.001 & 64.28 & 0.77 \\
\hline & Dominant (TT+CT vs. CC) & $0.98(0.92-1.04), 0.60$ & $1.00(0.87-1.15), 0.97$ & $<0.001$ & 66.41 & 0.95 \\
\hline & Homozygote (TT vs. CC) & $0.95(0.86-1.06), 0.40$ & $0.92(0.73-1.17), 0.52$ & 0.002 & 63.51 & 0.55 \\
\hline & Co-dominant (CT vs. CC) & $0.99(0.93-1.05), 0.81$ & $1.02(0.88-1.18), 0.77$ & $<0.001$ & 68.32 & 0.94 \\
\hline & Recessive (CC+CT vs. TT) & $0.96(0.87-1.06), 0.48$ & $0.91(0.72-1.15), 0.44$ & $<0.001$ & 66.47 & 0.50 \\
\hline \multirow[t]{5}{*}{ Mixed } & Allele Contrast (T vs. C) & $0.93(0.80-1.09), 0.41$ & $0.96(0.76-1.22), 0.77$ & 0.12 & 44.12 & 0.74 \\
\hline & Dominant (TT+CT vs. CC) & $0.96(0.79-1.16), 0.71$ & $0.97(0.65-1.45), 0.91$ & 0.01 & 68.55 & 0.92 \\
\hline & Homozygote (TT vs. CC) & 0.75 (0.51-1.09), 0.13 & $0.76(0.52-1.10), 0.15$ & 0.64 & 0 & 0.79 \\
\hline & Co-dominant (CT vs. CC) & $1.00(0.82-1.22), 0.97$ & $0.97(0.62-1.52), 0.91$ & 0.006 & 72.68 & 0.83 \\
\hline & Recessive (CC+CT vs. TT) & $0.79(0.55-1.13), 0.21$ & $0.80(0.56-1.15), 0.24$ & 0.48 & 0 & 0.82 \\
\hline
\end{tabular}

\subsection{Meta-analysis of MTRR A66G gene polymorphism in prostate cancer}

For MTRR A66G meta-analysis, total eight studies with 3,631 cases and 5,076 controls [39, 40, $45,48,49,50,62$, present study]. Out of which, three were Asian, three were Caucasian and two were of mixed ethnicities. Insignificant association was found in the A66G gene polymorphism in all the genetics models with high heterogeneity (For allele contrast model $\mathrm{OR}_{\mathrm{Gvs} . \mathrm{A}}=1.03$; 95\%CI: $0.90-1.18 ; \mathrm{p}=0.59 ; \mathrm{I}^{2}=62.43 \%$; for co-dominant model $\mathrm{OR}_{\mathrm{AGvs} . \mathrm{AA}}=0.90 ; 95 \%$ CI: $0.74-$ $1.10 ; \mathrm{p}=0.32 ; \mathrm{I}^{2}=56.11 \%$; for homozygote model $\mathrm{OR}_{\mathrm{GGvs} . \mathrm{AA}}=0.95 ; 95 \% \mathrm{CI}=0.83-1.08 ; \mathrm{p}=0.48$; $\mathrm{I}^{2}=20 \%$; for dominant model $\mathrm{OR}_{\mathrm{GG}+\mathrm{AGv} . \mathrm{AA}}=0.94 ; 95 \% \mathrm{CI}$ : $0.85-1.03 ; \mathrm{p}=0.20 ; \mathrm{I}^{2}=48.08 \%$; and for recessive model $\mathrm{OR}_{\mathrm{AA}+\mathrm{AGvs} . \mathrm{GG}}=1.21 ; 95 \% \mathrm{CI}=0.91-1.61 ; \mathrm{p}=0.18 ; \mathrm{I}^{2}=73.74 \%$ ) (Figure 2, Table 3).

n sub-group meta-analyses, no statistically significant association were observed in the Asian population (for $\mathrm{G}$ vs. $\mathrm{A}$ : $\mathrm{OR}=1.24 ; 95 \% \mathrm{CI}=0.81-1.89 ; \mathrm{p}=0.31 ; \mathrm{I}^{2}=77.76 \%$; for $\mathrm{GG}+\mathrm{AG}$ vs. AA: $\mathrm{OR}=0.99 ; 95 \% \mathrm{CI}=0.74-1.33 ; \mathrm{p}=0.98 ; \mathrm{I}^{2}=0 \%$; for $\mathrm{GG}$ vs. $\mathrm{AA}: \mathrm{OR}=1.12 ; 95 \% \mathrm{CI}=0.70-$ $1.81 ; \mathrm{p}=0.62 ; \mathrm{I}^{2}=0 \%$; for $\mathrm{AG}$ vs. AA: $\mathrm{OR}=0.93 ; 95 \% \mathrm{CI}=0.68-1.26 ; \mathrm{p}=0.64 ; \mathrm{I}^{2}=38.95 \%$; and for $\mathrm{AG}+\mathrm{AA}$ vs. $\mathrm{GG}$ : $\mathrm{OR}=1.58 ; 95 \% \mathrm{CI}=0.65-3.84 ; \mathrm{p}=0.30 ; \mathrm{I}^{2}=82.48 \%$ ) and in the Caucasian population (for $\mathrm{G}$ vs. $\mathrm{A}$ : $\mathrm{OR}=0.97 ; 95 \% \mathrm{CI}=0.90-1.03 ; \mathrm{p}=0.39 ; \mathrm{I}^{2}=0 \%$; for $\mathrm{GG}+\mathrm{AG}$ vs. $\mathrm{AA}$ : $\mathrm{OR}=0.94 ; 95 \% \mathrm{CI}=0.85-1.05 ; \mathrm{p}=0.32 ; \mathrm{I}^{2}=0 \%$; for $\mathrm{GG}$ vs. $\mathrm{AA}: \mathrm{OR}=0.94 ; 95 \% \mathrm{CI}=0.82-1.09$; $\mathrm{p}=0.45 ; \mathrm{I}^{2}=0 \%$; for AG vs. AA: $\mathrm{OR}=0.95 ; 95 \% \mathrm{CI}=0.85-1.06 ; \mathrm{p}=0.35 ; \mathrm{I}^{2}=0 \%$; and for AG+AA vs. GG: $\mathrm{OR}=0.97 ; 95 \% \mathrm{CI}=0.86-1.10 ; \mathrm{p}=0.72 ; \mathrm{I}^{2}=3.89 \%$ ) (Table 3 ). 
medRxiv preprint doi: https://doi.org/10.1101/2021.01.06.21249185; this version posted January 8, 2021. The copyright holder for this preprint (which was not certified by peer review) is the author/funder, who has granted medRxiv a license to display the preprint in perpetuity.

It is made available under a CC-BY-NC-ND 4.0 International license .

Table 3. Summary estimates for the odds ratio (OR) of MTRR A66G in various allele/genotype contrasts, the significance level ( $p$ value) of heterogeneity test $\left(Q\right.$ test), and the $I^{2}$ metric

\begin{tabular}{|c|c|c|c|c|c|c|}
\hline & Genetic Contrast & $\begin{array}{l}\text { Fixed effect } \\
\text { OR }(95 \% \text { CI }), p\end{array}$ & $\begin{array}{l}\text { Random effect } \\
\text { OR }(95 \% \text { CI }), p\end{array}$ & $\begin{array}{l}\text { Heterogeneity } \\
\text { p-value (Q } \\
\text { test) }\end{array}$ & $I^{2}(\%)$ & $\begin{array}{l}\text { Publication } \\
\text { Bias (p of } \\
\text { Egger's test) }\end{array}$ \\
\hline \multirow[t]{5}{*}{ All } & Allele Contrast (G vs. A) & $0.99(0.93-1.05), 0.81$ & $1.03(0.90-1.18), 0.59$ & 0.009 & 62.43 & 0.40 \\
\hline & Dominant (GG+AG vs. AA) & $0.94(0.85-1.03), 0.20$ & $0.94(0.79-1.12), 0.51$ & 0.06 & 48.08 & 0.42 \\
\hline & Homozygote (GG vs. AA) & $0.95(0.83-1.08), 0.48$ & 0.97 (0.81-1.17), 0.78 & 0.26 & 20 & 0.95 \\
\hline & Co-dominant (AG vs. AA) & $0.93(0.84-1.02), 0.15$ & $0.90(0.74-1.10), 0.32$ & 0.02 & 56.11 & 0.22 \\
\hline & Recessive (AA+AG vs. GG) & $1.06(0.95-1.18), 0.28$ & $1.21(0.91-1.61), 0.18$ & $<0.001$ & 73.74 & 0.32 \\
\hline \multirow[t]{5}{*}{ Asian } & Allele Contrast (G vs. A) & $1.23(1.01-1.50), 0.03$ & 1.24 (0.81-1.89), 0.31 & 0.01 & 77.76 & 0.94 \\
\hline & Dominant (GG+AG vs. AA) & 0.99 (0.74-1.33), 0.98 & 0.99 (0.74-1.33), 0.98 & 0.68 & 0 & 0.32 \\
\hline & Homozygote (GG vs. AA) & $1.12(0.70-1.81), 0.62$ & $1.13(0.70-1.81), 0.61$ & 0.60 & 0 & 0.13 \\
\hline & Co-dominant (AG vs. AA) & $0.93(0.68-1.26), 0.64$ & $0.86(0.55-1.33), 0.51$ & 0.19 & 38.95 & 0.08 \\
\hline & Recessive (AA+AG vs. GG) & $1.93(1.36-2.72),<0.001$ & $1.58(0.65-3.84), 0.30$ & 0.003 & 82.48 & 0.22 \\
\hline \multirow[t]{5}{*}{ Caucasian } & Allele Contrast (G vs. A) & $0.97(0.90-1.03), 0.39$ & $0.97(0.90-1.03), 0.39$ & 0.50 & 0 & 0.67 \\
\hline & Dominant (GG+AG vs. AA) & $0.94(0.85-1.05), 0.32$ & $0.94(0.85-1.05), 0.31$ & 0.72 & 0 & 0.21 \\
\hline & Homozygote (GG vs. AA) & $0.94(0.82-1.09), 0.45$ & $0.94(0.82-1.09), 0.45$ & 0.46 & 0 & 0.70 \\
\hline & Co-dominant (AG vs. AA) & $0.95(0.85-1.06), 0.35$ & $0.95(0.85-1.06), 0.35$ & 0.75 & 0 & 0.18 \\
\hline & Recessive (AA+AG vs. GG) & $0.97(0.86-1.10), 0.72$ & $0.98(0.86-1.11), 0.75$ & 0.35 & 3.89 & 0.94 \\
\hline \multirow[t]{5}{*}{ Mixed } & Allele Contrast (G vs. A) & $0.93(0.72-1.18), 0.56$ & $0.91(0.59-1.38), 0.65$ & 0.09 & 64.81 & NA \\
\hline & Dominant (GG+AG vs. AA) & $0.78(0.55-1.12), 0.19$ & $0.42(0.05-3.11), 0.39$ & $<0.001$ & 91.48 & NA \\
\hline & Homozygote (GG vs. AA) & $0.81(0.42-1.55), 0.53$ & $0.56(0.08-3.57), 0.54$ & 0.01 & 82.09 & NA \\
\hline & Co-dominant (AG vs. AA) & $0.73(0.50-1.07), 0.11$ & $0.40(0.05-2.99), 0.37$ & $<0.001$ & 91.33 & NA \\
\hline & Recessive (AA+AG vs. GG) & $1.25(0.70-2.24), 0.44$ & $1.25(0.70-2.24), 0.44$ & 0.86 & 0 & NA \\
\hline
\end{tabular}

\subsection{Sensitivity analysis}

Those studies which were not in the agreement with Hardy-Weinberg equilibrium (HWE) were excluded to conduct the sensitivity analysis. For MTHFR C677T gene polymorphism six studies were not in HWE [39, 42, 44, 45, 61, 65]. After removal of these studies no significant association was found in any genetic model in overall and in sub-group analyses. Similarly for the MTRR A66G gene polymorphism two studies were deviated from HWE [45, present study]. We removed both the studies and found no significant association in overall as well as in any sub-group meta-analyses.

\subsection{Publican bias}

Symmetrical funnel plots were observed in all five contrast genetic models (Figure 3). The pvalues of Egger's test were more than 0.05 in all the genetic contrast models which statistically confirms the symmetry of funnel plots in the overall and sub-group meta-analyses (Table 3).

\section{Discussion}

The concentration of folate is largely determined by dietary intakes [68], and low circulating level of folate increases the risk of colon, breast and pancreatic cancer [69], while the risk of other cancers may be increases in a high folate concentration [70]. Folate is responsible for the synthesis, repair and methylation of DNA [49, 71-74]. Folate deficiency may leads to an increase in the mis-incorporation of uracil base in DNA. During repair of uracil in DNA, a transient nick is formed and two opposing nicks could lead to a break in the chromosome which could contribute to the increase risk of cancer [3]. These findings were further confirmed in the studies conducted on the lymphocytes of rats that had been maintained on a folate-deficient diet $[75,76]$. Various enzymes of the folate pathway are coded by the different genes and polymorphisms in 
medRxiv preprint doi: https://doi.org/10.1101/2021.01.06.21249185; this version posted January 8, 2021. The copyright holder for this preprint (which was not certified by peer review) is the author/funder, who has granted medRxiv a license to display the preprint in perpetuity. It is made available under a CC-BY-NC-ND 4.0 International license .

those genes may lead to differential activity of the enzymes. The most studied gene polymorphisms are MTHFR C677T and MTRR A66G.

The results of the present case-control study shows that the CT genotype (OR=1.92; 95\% CI: 1.06-3.48, $\mathrm{p}=0.02)$ and the dominant model $(\mathrm{TT}+\mathrm{CT})(\mathrm{OR}=1.85 ; 95 \% \mathrm{CI}: 1.05-3.30, \mathrm{p}=0.03)$ of the MTHFR C677T gene polymorphism were significantly associated with the etiology of prostate cancer. While the $\mathrm{T}$ allele of the MTHFR C677T polymorphism was marginally associated with the prostate cancer $(\mathrm{OR}=1.67 ; 95 \% \mathrm{CI}: 0.99-2.84, \mathrm{p}=0.05)$. Our results supported the findings of various previous studies [36, 38, 39, 41, 64].

In case of the MTRR A66G gene polymorphism the $\mathrm{G}$ allele was found to be strongly associated with the etiology of the prostate cancer $(\mathrm{OR}=1.92 ; 95 \% \mathrm{CI}: 1.35-2.73, \mathrm{p}=0.0002)$. Our result also confirmed the outcome of various previous published studies [39, 40, 45, 48, 49, 62].

The results of present meta-analysis showed no evidence of association of MTHFR C677T and MTRR A66G gene polymorphisms in overall and sub-group analyses with prostate cancer susceptibility.

During literature search, we found seven meta-analyses [48, 77-82] that were examined the effect of MTHFR C677T gene polymorphism in prostate cancer risk, but no consistent conclusion was achieved. Except two studies [80, 81], other five meta-analyses [48, 77-79, 82] reported no significant association between MTHFR C677T polymorphism and prostate cancer risk. Abedinzadeh et al. [80] have found significant association only in the Asian population $(\mathrm{OR}=1.299 ; 95 \% \mathrm{CI}=1.121-1.506 ; \mathrm{p}=0.001)$. Chen et al. [81] have reported significant association between MTHFR C677T polymorphism with prostate cancer risk in the East Asian population using co-dominant model (CT vs. $\mathrm{CC}+\mathrm{TT}$ : $\mathrm{OR}=1.32 ; 95 \% \mathrm{CI}=1.02-1.70 ; \mathrm{p}=0.03$ ).

For MTRR A66G gene polymorphism, one meta-analysis was found during the literature search [48]. They conducted their meta-analysis with four studies and found no significant association in overall analysis.

Meta-analysis is a tool which combines different small clinical trials and increases the power of the study by reducing the type I and II errors. In recent time, meta-analysis becomes the favorite choice of researchers and numerous meta-analyses were published in past decades e.g. Down syndrome [83, 84], neural tube defects [85], Glucose 6-phosphate dehydrogenase deficiency [86], osteoporosis [87], bipolar disorder [88], depression [89], schizophrenia [90, 91], Alzheimer [92], epilepsy [93], breast cancer [94, 95], colorectal cancer [96], esophageal cancer [97], and prostate cancer [98].

The present meta-analysis has some merits over the other previously published meta-analyses such as- i) this is the largest study on the bases of number of included studies (25 studies for MTHFR C677T and eight studies for MTRR A66G) as well as on the bases of number of subjects included (26,394 subjects for MTHFR C677T and 8,707 subjects for MTRR A66G); ii) two gene polymorphisms (MTHFR C677T and MTRR A66G) are considered in meta-analysis; iii) no publication bias was found; and iv) studies were searched by using four different databases viz. PubMed, Science Direct, Springer Link and Google scholar. Here we also want to acknowledge few limitations of the meta-analysis like i) we used only crude odds ratios; ii) only English language publications were included; and iii) the effect of the hyperhomocystenemia and folate deficiency were not considered. 
medRxiv preprint doi: https://doi.org/10.1101/2021.01.06.21249185; this version posted January 8, 2021. The copyright holder for this preprint (which was not certified by peer review) is the author/funder, who has granted medRxiv a license to display the preprint in perpetuity.

\section{Conclusions}

The data of our case-control study revealed that the $\mathrm{T}$ allele, CT genotype, and dominant (TT+CT) model of MTHFR C677T gene polymorphism and G allele of MTRR A66G gene polymorphism were significantly associated with the etiology of prostate cancer risk. In future, larger case- control association studies from different global populations are required to find out the exact association between these two polymorphisms (C677T and A66G) and prostate cancer risk. In addition, effects of higher concentration of homocysteine and lower concentration of folate should also be evaluated in prostate cancer patients.

\section{Acknowledgments:}

Upendra Yadav is highly grateful to VBS Purvanchal University, Jaunpur for providing financial assistance to him in the form of PDF.

\section{References}

1. Bray F, Ferlay J, Soerjomataram I, Siegel RL, Torre LA, Jemal A. Global cancer statistics 2018: GLOBOCAN estimates of incidence and mortality worldwide for 36 cancers in 185 countries. CA Cancer J Clin. 2018;68(6):394-424.

2. Hsing AW, Chokkalingam AP. Prostate cancer epidemiology. Front Biosci. 2006;11:1388413.

3. Blount BC, Mack MM, Wehr CM, MacGregor JT, Hiatt RA, Wang G, et al. Folate deficiency causes uracil misincorporation into human DNA and chromosome breakage: implications for cancer and neuronal damage. Proc Natl Acad Sci USA. 1997;94:3290-5.

4. Duthie SJ, Narayanan S, Brand GM, Pirie L, Grant G. Impact of folate deficiency on DNA stability. J Nutr. 2002;132(8 Suppl.):2444S-49S.

5. Yadav U, Kumar P, Gupta S, Rai V. Distribution of MTHFR C677T gene polymorphism in healthy North Indian population and an updated meta-analysis. Indian J Clin Biochem. 2017;32(4):399-410.

6. Rai V, Yadav U, Kumar P, Mishra OP, Gupta S. Prevalence of Methylenetetrahydrofolate Reductase C677T Polymorphism. Int J Integr Biol. 2011;11(3):153-4.

7. Rai V, Yadav U, Kumar P, Yadav SK. Methylenetetrahydrofolate Reductase Polymorphism (C677T) in Muslim population of eastern Uttar Pradesh, India. Indian J Med Sci. 2010;64(5):219-23.

8. Rai V, Yadav U, Kumar P. Prevalence of Methylenetetrahydrofolate Reductase C677T Polymorphism in eastern Uttar Pradesh. Indian J Hum Genet. 2012;18(1):43-6.

9. Rai V, Yadav U, Kumar P. Genotype prevalence and allele frequencies of 5, 10methylenetetrahydrofolate reductase (MTHFR) C677T mutation in two caste groups of India. Cell Mol Biol (Noisy-le-grand). 2012;15(58):Suppl:OL1695-701.

10. Yadav U, Kumar P, Rai V. Distribution of methionine synthase reductase (MTRR) gene A66G polymorphism in Indian population. Indian J Clin Biochem (In press). 2019; DOI: 10.1007/s12291-019-00862-9. 
medRxiv preprint doi: https://doi.org/10.1101/2021.01.06.21249185; this version posted January 8, 2021. The copyright holder for this preprint (which was not certified by peer review) is the author/funder, who has granted medRxiv a license to display the preprint in perpetuity. It is made available under a CC-BY-NC-ND 4.0 International license .

11. Rai V, Yadav U, Kumar P, Gupta S. Uttar Pradesh Methionine Synthase Reductase A66G Polymorphism in Rural Population of Uttar Pradesh (India). Biotechnology. 2011;10(2):2203.

12. Rai V, Yadav U, Kumar P. MTRR A66G polymorphism among two caste groups of Uttar Pradesh (India). Indian J Med Sci. 2012;66(5):136-40.

13. Rai V, Yadav U, Kumar P, Yadav SK. Analysis of methionine synthase reductase polymorphism (A66G) in Indian Muslim population. Indian J Hum Genet. 2013;19(2):183-7.

14. Ferlazzo N, Currò M, Zinellu A, Caccamo D, Isola G, Ventura V, et al. Influence of MTHFR Genetic Background on p16 and MGMT Methylation in Oral Squamous Cell Cancer. Int J Mol Sci. 2017;18(4):724.

15. Liu Y, Zhou LS, Xu XM, Deng LQ, Xiao QK. Association of dietary intake of folate, vitamin B6 and B12 and MTHFR genotype with breast cancer risk. Asian Pac J Cancer Prev. 2013;14(9):5189-92.

16. Lei QR, Yang X, Miao CM, Wang JC, Yang Y. Relationship between granulomatous lobular mastitis and methylene tetrahydrofolate reductase gene polymorphism. World J Clin Cases. 2020;8(18):4017-21.

17. Zhu Q, Jin Z, Yuan Y, Lu Q, Ge D, Zong M. Impact of MTHFR gene C677T polymorphism on Bcl-2 gene methylation and protein expression in colorectal cancer. Scand J Gastroenterol. 2011;46(4):436-45.

18. Ozen F, Sen M, Ozdemir O. Methylenetetrahydrofolate Reductase Gene Germ-Line C677T and A1298C SNPs are Associated with Colorectal Cancer Risk in the Turkish Population. Asian Pac J Cancer Prev. 2014;15:7731-5.

19. Xia LZ, Liu Y, Xu XZ, Jiang PC, Ma G, Bu XF, et al. Methylenetetrahydrofolate reductase C677T and A1298C polymorphisms and gastric cancer susceptibility. World J Gastroenterol. 2014;20:11429-38.

20. Mazzuca F, Borro M, Botticelli A, Aimati L, Gentile G, Capalbo C, et al. Effect of MTHFR Polymorphisms on Gastrointestinal Cancer Risk in Italy. World J Oncol. 2015;6(4):394-7.

21. Cui LH, Shin MH, Kim HN, Song HR, Piao JM, Kweon SS, et al. Methylenetetrahydrofolate reductase $\mathrm{C} 677 \mathrm{~T}$ polymorphism in patients with lung cancer in a Korean population. BMC Med Genet. 2011;12:28.

22. Tong W, Tong G, Jin D, Lv Q. MTHFR C677T and A1298C polymorphisms and lung cancer risk in a female Chinese population. Cancer Manag Res. 2018;10:4155-4161.

23. Suzuki T, Matsuo K, Sawaki A, Mizuno N, Hiraki A, Kawase T, et al. Alcohol drinking and one-carbon metabolism-related gene polymorphisms on pancreatic cancer risk. Cancer Epidemiol Biomarkers Prev. 2008;17(10):2742-7.

24. Liu XM, Liu FH, Tang Y, Li Q. MTHFR C677T polymorphism and pancreatic cancer risk: a meta-analysis. Asian Pac J Cancer Prev. 2012;13(8):3763-6.

25. Izmirli M, Inandiklioglu N, Abat D, Alptekin D, Demirhan O, Tansug Z, et al. MTHFR gene polymorphisms in bladder cancer in the Turkish population. Asian Pac J Cancer Prev. 2011;12(7):1833-5.

26. Safarinejad MR, Shafiei N, Safarinejad S. Genetic susceptibility of methylenetetrahydrofolate reductase (MTHFR) gene C677T, A1298C, and G1793A 
medRxiv preprint doi: https://doi.org/10.1101/2021.01.06.21249185; this version posted January 8, 2021. The copyright holder for this preprint (which was not certified by peer review) is the author/funder, who has granted medRxiv a license to display the preprint in perpetuity. It is made available under a CC-BY-NC-ND 4.0 International license .

polymorphisms with risk for bladder transitional cell carcinoma in men. Med Oncol. 2011;28 Suppl 1:S398-412.

27. Gong JM, Shen Y, Shan WW, He YX. The association between MTHFR polymorphism and cervical cancer. Sci Rep. 2018;8(1):7244.

28. Suzuki T, Matsuo K, Hiraki A, Saito T, Sato S, Yatabe Y, et al. Impact of one-carbon metabolism-related gene polymorphisms on risk of lung cancer in Japan: a case control study. Carcinogenesis. 2007;28(8):1718-25.

29. Aksoy-Sagirli P, Erdenay A, Kaytan-Saglam E, Kizir A. Association of Three Single Nucleotide Polymorphisms in MTR and MTRR Genes with Lung Cancer in a Turkish Population. Genet Test Mol Biomarkers. 2017;21(7):428-32.

30. Zhang J, Zhou YW, Shi HP, Wang YZ, Li GL, Yu HT, et al. 5,10-Methylenetetrahydrofolate reductase (MTHFR), methionine synthase (MTRR), and methionine synthase reductase (MTR) gene polymorphisms and adult meningioma risk. J Neurooncol. 2013;115(2):233-9.

31. Otani T, Iwasaki M, Hanaoka T, Kobayashi M, Ishihara J, Natsukawa S, et al. Folate, vitamin B6, vitamin B12, and vitamin B2 intake, genetic polymorphisms of related enzymes, and risk of colorectal cancer in a hospital-based case-control study in Japan. Nutr Cancer. 2005;53(1):42-50.

32. Zhou D, Mei Q, Luo H, Tang B, Yu P. The polymorphisms in methylenetetrahydrofolate reductase, methionine synthase, methionine synthase reductase, and the risk of colorectal cancer. Int J Biol Sci. 2012;8(6):819-30.

33. Galbiatti AL, Ruiz MT, Maniglia JV, Raposo LS, Pavarino-Bertelli EC, Goloni-Bertollo EM. Head and neck cancer: genetic polymorphisms and folate metabolism. Braz J Otorhinolaryngol. 2012;78(1):132-9.

34. Suzuki T, Matsuo K, Hirose K, Hiraki A, Kawase T, Watanabe M, et al. One-carbon metabolism-related gene polymorphisms and risk of breast cancer. Carcinogenesis. 2008;29(2):356-62.

35. Kimura F, Franke KH, Steinhoff C, Golka K, Roemer HC, Anastasiadis AG, et al. Methyl group metabolism gene polymorphisms and susceptibility to prostatic carcinoma. Prostate. 2000;45:225-31.

36. Heijmans B, Boer J, Suchiman H, Cornelisse C, Westendorp R, Kromhout D et al. A common variant of the methylenetetrahydrofolate reductase gene (1p36) is associated with an increased risk of cancer. Cancer Res. 2003;63:1249-53.

37. Cicek M, Nock N, Li L, Conti D, Casey G, Witte J. Relationship between methylenetetrahydrofolate reductase C677T and A1298C genotypes and haplotypes and prostate cancer risk and aggressiveness. Cancer Epidemiol Biomarkers Prevent. 2004;13:1331-6.

38. Van Guelpen BR, Wirén SM, Bergh AR, Hallmans G, Stattin PE, Hultdin J. Polymorphisms of methylenetetrahydrofolate reductase and the risk of prostate cancer: a nested case-control study. Eur J Cancer Prev. 2006;15(1):46-50.

39. Marchal C, Redondo M, Reyes-Engel A, Perea-Milla E, Gaitan M, Machuca J et al. Association between polymorphisms of folate-metabolizing enzymes and risk of prostate cancer. Eur J Surg Oncol. 2008;34:805-10. 
medRxiv preprint doi: https://doi.org/10.1101/2021.01.06.21249185; this version posted January 8, 2021. The copyright holder for this preprint (which was not certified by peer review) is the author/funder, who has granted medRxiv a license to display the preprint in perpetuity. It is made available under a CC-BY-NC-ND 4.0 International license .

40. Cai D, Ning L, Pan C, Liu X, Bu R, Chen X, et al. Association of polymorphisms in folate metabolic genes and prostate cancer risk: a case-control study in a Chinese population. $\mathrm{J}$ Genet. 2010;89:263-7.

41. Safarinejad MR, Shafiei N, Safarinejad S. Relationship between three polymorphisms of methylenetetrahydrofolate reductase (MTHFR C677T, A1298C, and G1793A) gene and risk of prostate cancer: a case-control study. Prostate. 2010;70:1645-57.

42. Kobayashi LC, Limburg H, Miao Q, Woolcott C, Bedard LL, Massey TE et al. Folate intake, alcohol consumption, and the methylenetetrahydrofolate reductase (MTHFR) C677T gene polymorphism: influence on prostate cancer risk and interactions. Front Oncol. 2012;2:100.

43. Mandal RK, Nissar K, Mittal RD. Genetic variants in metabolizing genes NQO1, NQO2, MTHFR and risk of prostate cancer: a study from North India. Mol Biol Rep. 2012;39(12):11145-52.

44. de Vogel S, Meyer K, Fredriksen A, Ulvik A, Ueland PM, Nygård O, et al. Serum folate and vitamin B12 concentrations in relation to prostate cancer risk--a Norwegian population-based nested case-control study of 3000 cases and 3000 controls within the JANUS cohort. Int J Epidemiol. 2013;42(1):201-10.

45. López-Cortés A, Jaramillo-Koupermann G, Muñoz MJ, Cabrera A, Echeverría C, Rosales F, et al. Genetic Polymorphisms in MTHFR (C677T, A1298C), MTR (A2756G) and MTRR (A66G) Genes Associated With Pathological Characteristics of Prostate Cancer in the Ecuadorian Population. Am J Med Sci. 2013;346(6):447-54.

46. Ghasemi S, Tavakoli A, Moghadam M, Zargar MA, Abbaspour M, Hatamnejadian N, et al. Risk of prostate cancer and thrombosis-related factor polymorphisms. Biomed Rep. 2014;2(1):53-6.

47. Wu JL, Zhou SX, Zhao R, Zhang X, Chang K, Gu CY, et al. MTHFR c.677C>T Inhibits Cell Proliferation and Decreases Prostate Cancer Susceptibility in the Han Chinese Population in Shanghai. Sci Rep. 2016;6:36290.

48. Collin SM, Metcalfe C, Zuccolo L, Lewis SJ, Chen L, Cox A et al. Association of folatepathway gene polymorphisms with the risk of prostate cancer: a population-based nested casecontrol study, systematic review, and meta-analysis. Cancer Epidemiol Biomarkers Prevent. 2009; 18:2528-39.

49. Jackson MD, Tulloch-Reid MK, McFarlane-Anderson N, Watson A, Seers V, Bennett FI, et al. Complex interaction between serum folate levels and genetic polymorphisms in folate pathway genes: biomarkers of prostate cancer aggressiveness. Genes Nutr. 2013;8(2):199207.

50. Basir A. Methionine Synthase Reductase-A66G and -C524T Single Nucleotide Polymorphisms and Prostate Cancer: A Case-Control Trial. Asian Pac J Cancer Prev. 2019;20(5):1445-51.

51. Bartlett JMS, White A. Extraction of DNA from whole blood. In Bartlett JMS and Stirling D (Ed.) Methods in Molecular Biology. Vol 226. PCR Protocols 2nd ed. 2003;pp.29-31. Humana Press Inc. Totowa, NJ. 
medRxiv preprint doi: https://doi.org/10.1101/2021.01.06.21249185; this version posted January 8, 2021. The copyright holder for this preprint (which was not certified by peer review) is the author/funder, who has granted medRxiv a license to display the preprint in perpetuity. It is made available under a CC-BY-NC-ND 4.0 International license .

52. Frosst P, Blom HJ, Milos R, Goyette P, Sheppard CA, Matthews RG, et al. A candidate genetic risk factor for vascular disease: a common mutation in methylenetetrahydrofolate reductase. Nat Genet. 1995;10:111-3.

53. Wilson A, Platt R, Wu Q, Leclerc D, Christensen B, Yang H, et al. A common variant in methionine synthase reductase combined with low cobalamin (vitamin B12) increases risk for spina bifida. Mol Genet Metab. 1999;67(4):317-23.

54. Mantel N, Haenszel W. Statistical aspects of the analysis of data from retrospective studies of disease. J Natl Cancer Inst. 1959;22(4):719-48.

55. DerSimonian R, Laird N. Meta-analysis in clinical trials. Control Clin Trials. 1986;7:177-88.

56. Higgins JP, Thompson SG. Quantifying heterogeneity in a meta-analysis. Stat Med. 2002;21(11):1539-58.

57. Egger M, Davey Smith G, Schneider M, Minder C. Bias in meta-analysis detected by a simple, graphical test. BMJ. 1997;315:629-34.

58. Wallace BC, Dahabreh IJ, Trikalinos TA, Lau J, Trow P et al. Closing the gap between methodologists and end users: R as a computational back-end. J Stat Software. 2013;49:1-15.

59. Singal R, Ferdinand L, Das P, Reis I, Schlesselman J. Polymorphisms in the methylenetetrahydrofolate reductase gene and prostate cancer risk. Int J Oncol. 2004;25:146571.

60. Johansson M, Van Guelpen B, Hultdin J, Wiklund F, Adami HO, Bälter K, et al. The MTHFR 677C --> T polymorphism and risk of prostate cancer: results from the CAPS study. Cancer Causes Control. 2007;18(10):1169-74.

61. Reljic A, Simundic A, Topic E, Nikolac N, Justinic D, Stefanovic M. The methylenetetrahydrofolate reductase (MTHFR) C677T polymorphism and cancer risk: the Croatian case-control study. Clin Biochem. 2007;40:981-5.

62. Stevens VL, Rodriguez C, Sun J, Talbot JT, Thun MJ, Calle EE. No association of single nucleotide polymorphisms in one-carbon metabolism genes with prostate cancer risk. Cancer Epidemiol Biomarkers Prev. 2008;17:3612-4.

63. Muslumanoglu MH, Tepeli E, Demir S, Uludag A, Uzun D, Atli E, et al. The analysis of the relationship between A1298C and C677T polymorphisms of the MTHFR gene with prostate cancer in Eskisehir population. Genet Test Mol Biomarkers. 2009;13:641-5.

64. Wu HC, Chang CH, Tsai RY, Lin CH, Wang RF, Tsai CW, et al. Significant association of methylenetetrahydrofolate reductase single nucleotide polymorphisms with prostate cancer susceptibility in taiwan. Anticancer Res. 2010;30:3573-7.

65. Küçükhüseyin Ö, Kurnaz Ö, Akadam-Teker AB, Narter F, Yılmaz-Aydoğan H, İsbir T. Effects of the MTHFR C677T polymorphism on prostate specific antigen and prostate cancer. Asian Pac J Cancer Prev. 2011;12(9):2275-8.

66. Fard-Esfahani P, Mohammadi Torbati P, Hashemi Z, Fayaz S, Golkar M. Analysis of relation between C677T genotype in MTHFR gene and prostatic cancer in Iranian males. Acta Med Iran. 2012;50(10):657-63.

67. Vidal AC, Grant DJ, Williams CD, Masko E, Allott EH, Shuler K, et al. Associations between Intake of Folate, Methionine, and Vitamins B-12, B-6 and Prostate Cancer Risk in American Veterans. J Cancer Epidemiol. 2012;2012:957467. 
medRxiv preprint doi: https://doi.org/10.1101/2021.01.06.21249185; this version posted January 8, 2021. The copyright holder for this preprint (which was not certified by peer review) is the author/funder, who has granted medRxiv a license to display the preprint in perpetuity. It is made available under a CC-BY-NC-ND 4.0 International license .

68. Selhub J, Jacques PF, Rosenberg IH, Rogers G, Bowman BA, Gunter EW et al. Serum total homocysteine concentrations in the third National Health and Nutrition Examination Survey (1991-1994): population reference ranges and contribution of vitamin status to high serum concentrations. Ann Intern Med. 1999;131(5):331-9.

69. Ulrich CM. Folate and cancer prevention: a closer look at a complex picture. Am J Clin Nutr. 2007;86:271-3.

70. Stolzenberg-Solomon RZ, Chang SC, Leitzmann MF, Johnson KA, Johnson C, Buys SS et al. Folate intake, alcohol use, and postmenopausal breast cancer risk in the Prostate, Lung, Colorectal, and Ovarian Cancer Screening Trial. Am J Clin Nutr. 2006;83(4):895-904.

71. Duthie S. Folic acid deficiency and cancer: mechanisms of DNA instability. Br Med Bull. 1999;55:578-92.

72. Choi S, Mason J. Folate and carcinogenesis: an integrated scheme. J Nutr. 2000;130:129-32.

73. Wei Q, Shen H, Wang L, Duphorne C, Pillow P, Guo Z, et al. Association between low dietary folate intake and suboptimal cellular DNA repair capacity. Cancer Epidemiol Biomarkers Prevent. 2003;12:963-9.

74. Shen H, Newmann A, Hu Z, Zhang Z, Xu Y, Wang L. et al. Methylenetetrahydrofolate reductase polymorphisms/haplotypes and risk of gastric cancer: a case-control analysis in China. Oncol Rep. 2005;13:355-60.

75. Duthie SJ, Narayanan S, Blum S, Piric L, Brand G. Folate deficiency in vitro induces uracil misincorporation and DNA hypomethylation and inhibits DNA excision repair in immortalized normal colon epithelial cells. Nutr Cancer. 2000;37:245-51.

76. Mattson MP, Chan SL, Duan W. Modification of brain aging and neurodegenerative disorders by genes, diet, and behavior. Physiol Rev. 2002;82(3):637-72.

77. Bai JL, Zheng MH, Xia X, Ter-Minassian M, Chen YP, Chen F. MTHFR C677T polymorphism contributes to prostate cancer risk among Caucasians: A meta-analysis of 3511 cases and 2762 controls. Eur J Cancer. 2009;45:1443-9.

78. Li XL, Xu JH. MTHFR polymorphism and the risk of prostate cancer: a meta-analysis of case-control studies. Prostate Cancer Prostatic Dis. 2012;15(3):244-9.

79. Zhang WB, Zhang JH, Pan ZQ, Yang QS, Liu B. The MTHFR C677T polymorphism and prostate cancer risk: new findings from a meta-analysis of 7306 cases and 8062 controls. Asian Pac J Cancer Prev. 2012;13(6):2597-604.

80. Abedinzadeh M, Zare-Shehneh M, Neamatzadeh H, Abedinzadeh M, Karami H. Association between MTHFR C677T Polymorphism and Risk of Prostate Cancer: Evidence from 22 Studies with 10,832 Cases and 11,993 Controls. Asian Pac J Cancer Prev. 2015;16(11):452530.

81. Chen Y, Hong C, Riley RD. An alternative pseudolikelihood method for multivariate random-effects meta-analysis. Stat Med. 2015;34(3):361-80.

82. Guo S, Jiang X, Chen X, Chen L, Li X, Jia Y. The protective effect of methylenetetrahydrofolate reductase $\mathrm{C} 677 \mathrm{~T}$ polymorphism against prostate cancer risk: Evidence from 23 case-control studies. Gene. 2015;565(1):90-5.

83. Rai V. Polymorphism in folate metabolic pathway gene as maternal risk factor for Down syndrome. Int J Biol Med Res. 2011;2(4):1055-60. 
medRxiv preprint doi: https://doi.org/10.1101/2021.01.06.21249185; this version posted January 8, 2021. The copyright holder for this preprint (which was not certified by peer review) is the author/funder, who has granted medRxiv a license to display the preprint in perpetuity. It is made available under a CC-BY-NC-ND 4.0 International license .

84. Rai V, Yadav U, Kumar P, Yadav SK, Mishra OP. Maternal methylenetetrahydrofolate reductase C677T polymorphism and Down syndrome risk: a meta-analysis from 34 studies. Plos One. 2014;9(9):e108552.

85. Yadav U, Kumar P, Yadav SK, Mishra OP, Rai V. Polymorphisms in folate metabolism genes as maternal risk factor for neural tube defects: an updated meta-analysis. Metab Brain Dis. 2015;30:7-14.

86. Kumar P, Yadav U, Rai V. Prevalence of Glucose-6-phosphate dehydrogenase deficiency in India: an updated meta-analysis. Egypt J Med Hum Genet. 2016;17:295-302.

87. Yadav U, Kumar P, Rai V. Vitamin D receptor (VDR) gene FokI, BsmI, ApaI and TaqI polymorphisms and osteoporosis risk: a meta-analysis. Egypt J Med Hum Genet (In press). 2020; doi.org/10.1186/s43042-020-00057-5.

88. Rai V. Evaluation of Methylenetetrahydrofolate Reductase Gene Variant (C677T) as Risk Factor for Bipolar Disorder. Cell Mol Biol. 2011;57:1558-66.

89. Rai V. Genetic polymorphisms of methylenetetrahydrofolate reductase (MTHFR) gene and susceptibility to depression in Asian population: a systematic meta-analysis. Cell Mol Biol. 2014;60(3):29-36.

90. Yadav U, Kumar P, Gupta S, Rai V. Role of MTHFR C677T gene polymorphism in the susceptibility of schizophrenia: an updated meta-analysis. Asian J Psychiatr. 2016;20:41-51.

91. Rai V, Yadav U, Kumar P, Yadav SK, Gupta S. Methylenetetrahydrofolate Reductase A1298C Genetic Variant and Risk of Schizophrenia: an updated meta-analysis. Indian J Med Res. 2017;145(4):437-47.

92. Rai V. Folate Pathway Gene Methylenetetrahydrofolate Reductase C677T Polymorphism and Alzheimer Disease Risk in Asian Population. Indian J Clin Biochem. 2016;31(3):245-52.

93. Rai V, Kumar P. Methylenetetrahydrofolate reductase C677T polymorphism and susceptibility to epilepsy. Neurol Sci. 2018;39(12):2033-41.

94. Kumar P, Yadav U, Rai V. Methylenetetrahydrofolate reductase gene C677T polymorphism and breast cancer risk: Evidence for genetic susceptibility. Meta Gene. 2015;6:72-84.

95. Rai V, Yadav U, Kumar P. Impact of Catechol-O-Methyltransferase Val 158Met (rs4680) Polymorphism on breast cancer Susceptibility in Asian population. Asian Pac J Cancer Prev. 2017;18(5):1243-50.

96. Rai V. Evaluation of the MTHFR C677T polymorphism as a risk factor for colorectal cancer in Asian populations. Asian Pac J Cancer Prev. 2016;16(18):8093-100.

97. Kumar P, Rai V. MTHFR C677T polymorphism and risk of esophageal cancer: an updated meta-analysis. Egypt J Med Hum Genet. 2018;19:273-84.

98. Yadav U, Kumar P, Rai V. Role of MTHFR A1298C gene polymorphism in the etiology of prostate cancer: a systematic review and updated meta-analysis. Egypt J Med Hum Genet. 2016;17(2):141-8. 
medRxiv preprint doi: https://doi.org/10.1101/2021.01.06.21249185; this version posted January 8, 2021. The copyright holder for this preprint (which was not certified by peer review) is the author/funder, who has granted medRxiv a license to display the preprint in perpetuity. It is made available under a CC-BY-NC-ND 4.0 International license.

\section{Figure legends}

Figure 1. Random effect forest plot of allele contrast model (T vs. C) of MTHFR C677T gene polymorphism. Results of individual and summary OR estimates, and 95\% CI of each study were shown. Horizontal lines represented $95 \%$ CI, and dotted vertical lines represent the value of the summary OR.

Figure 2. Random effect forest plot of allele contrast model (G vs. A) of MTRR A66G gene polymorphism.

Figure 3. Funnel plots of standard error by log odds ratio- a) for MTHFR C677T gene polymorphism; b) for MTRR A66G gene polymorphism. 


\section{Studies}

Kimura et al., 2000

Heijmans et al., 2003

Van Guelpen et al., 2006

Johansson et al., 2007

Reljic et al., 2007

Marchal et al., 2008

Stevens et al., 2008

Collin et al., 2009

Muslumanoglu et al., 2009

Küçükhüseyin et al., 2011

Kobayashi et al., 2012

de Vogel et al., 2013

Subgroup Caucasian $\left(I^{\wedge} 2=64.28 \%, P=0.001\right)$

Cicek et al., 2004

Singal et al., 2004

Vidal et al., 2012

Jackson et al., 2013

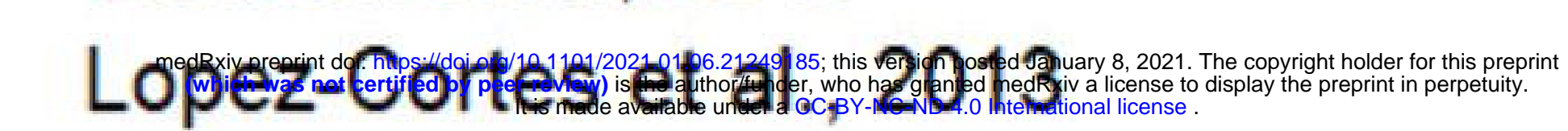

Subgroup Mixed $\left(\left.\right|^{\wedge} 2=44.12 \%, P=0.128\right)$

Cai et al., 2010

Safarinejad et al., 2010

Wu et al., 2010

Fard-Esfahani et al. 2012

Mandal et al., 2012

Ghasemi et al., 2014

Wu et al., 2016

Present Study

Subgroup Asian $\left(I^{\wedge} 2=56.87 \%, P=0.023\right)$

Overall $\left(I^{\wedge} 2=66.96 \%, P=0.000\right)$
Estimate (95\% C.I.)

$\begin{array}{ll}1.256 & (0.887,1.777) \\ 1.670 & (0.893,3.121) \\ 1.084 & (0.839,1.401) \\ 1.036 & (0.939,1.142) \\ 0.661 & (0.383,1.143) \\ 1.025 & (0.761,1.380) \\ 0.958 & (0.846,1.085) \\ 1.126 & (1.022,1.240) \\ 0.737 & (0.483,1.125) \\ 0.571 & (0.311,1.049) \\ 0.763 & (0.450,1.295) \\ 0.863 & (0.793, \\ 0.940) \\ 0.981 & (0.886,1.085)\end{array}$

$0.872(0.716,1.061)$

$0.793(0.437,1.437)$

$0.761(0.462,1.254)$

$0.998(0.648,1.537)$

$1.539(1.020,2.321)$

$0.966(0.763,1.223)$

$0.732(0.561,0.955)$

$0.780(0.589,1.033)$

$0.636(0.484,0.837)$

$1.036(0.628,1.708)$

$1.284(0.825,2.000)$

$0.649(0.156,2.708)$

$0.805(0.735,0.881)$

$1.670(0.993,2.811)$

$0.855(0.721,1.013)$

$0.935(0.858,1.018)$

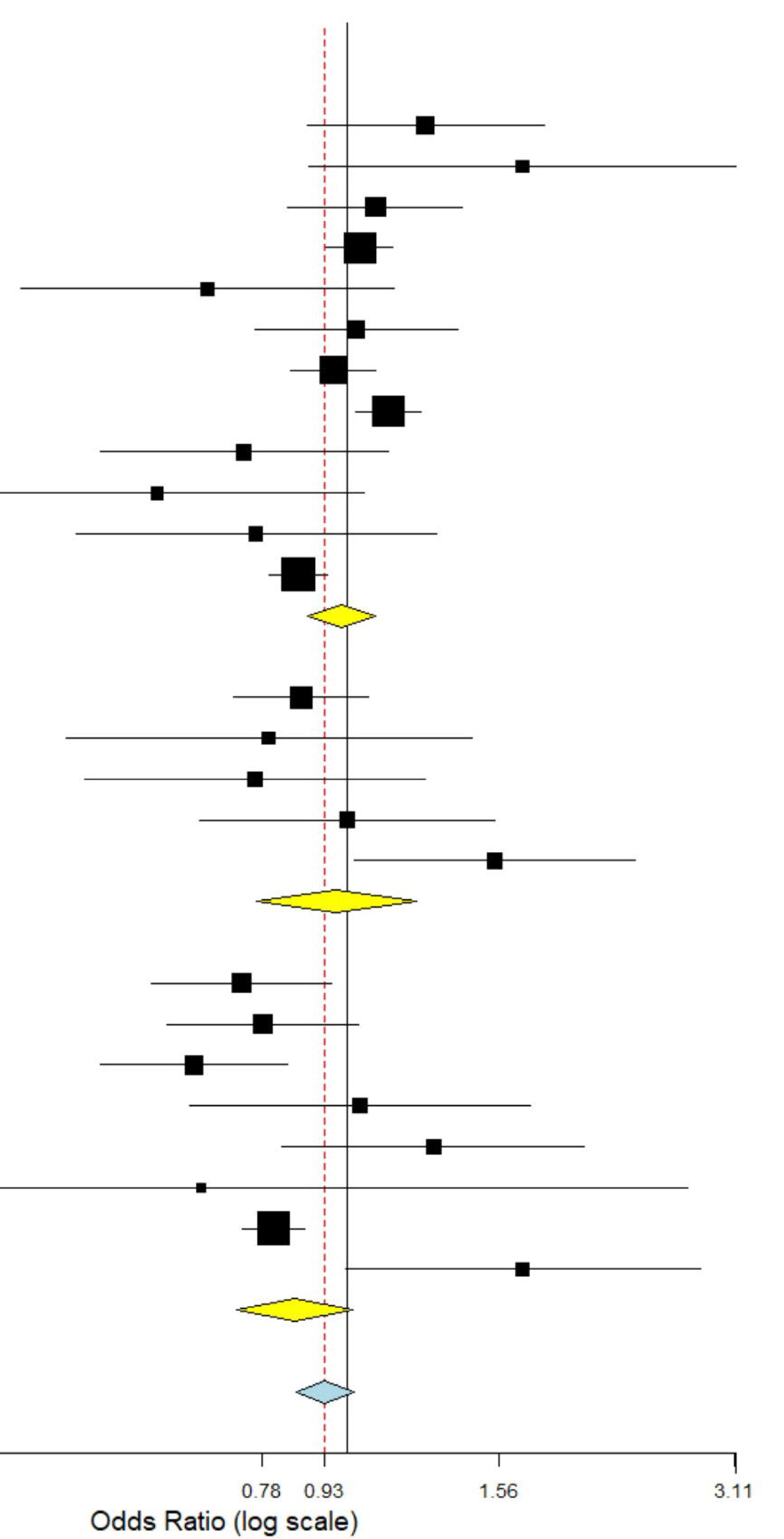




\section{Studies}

Marchal et al., 2008

Stevens et al., 2008

Collin et al., 2009

Subgroup Caucasian $\left(I^{\wedge} 2=0 \%, P=0.508\right)$

\section{Cairet al:; 2010}

Basir et al., 2019

Present Study

Subgroup Asian (I^2=77.76 \% , P=0.011)

Jackson et al., 2013

Lopez-Cortes et al., 2013

Subgroup Mixed $\left(I^{\wedge} 2=64.81 \%, P=0.092\right)$

Overall $\left(\left.\right|^{\wedge} 2=62.43 \%, P=0.009\right)$
Estimate (95\% C.I.)

$$
\begin{array}{lll}
1.001 & (0.755,1.328) \\
1.024 & (0.910,1.153) \\
0.940 & (0.862,1.026) \\
0.971 & (0.907,1.039) \\
& & \\
1.080 & (0.801,1.457) \\
0.920 & (0.627,1.349) \\
1.917 & (1.346,12.731) \\
1.240 & (0.814,1.890) \\
1.114 & (0.806,1.537) \\
0.725 & (0.496,1.061) \\
0.910 & (0.598,1.384) \\
1.036 & (0.909,1.181)
\end{array}
$$

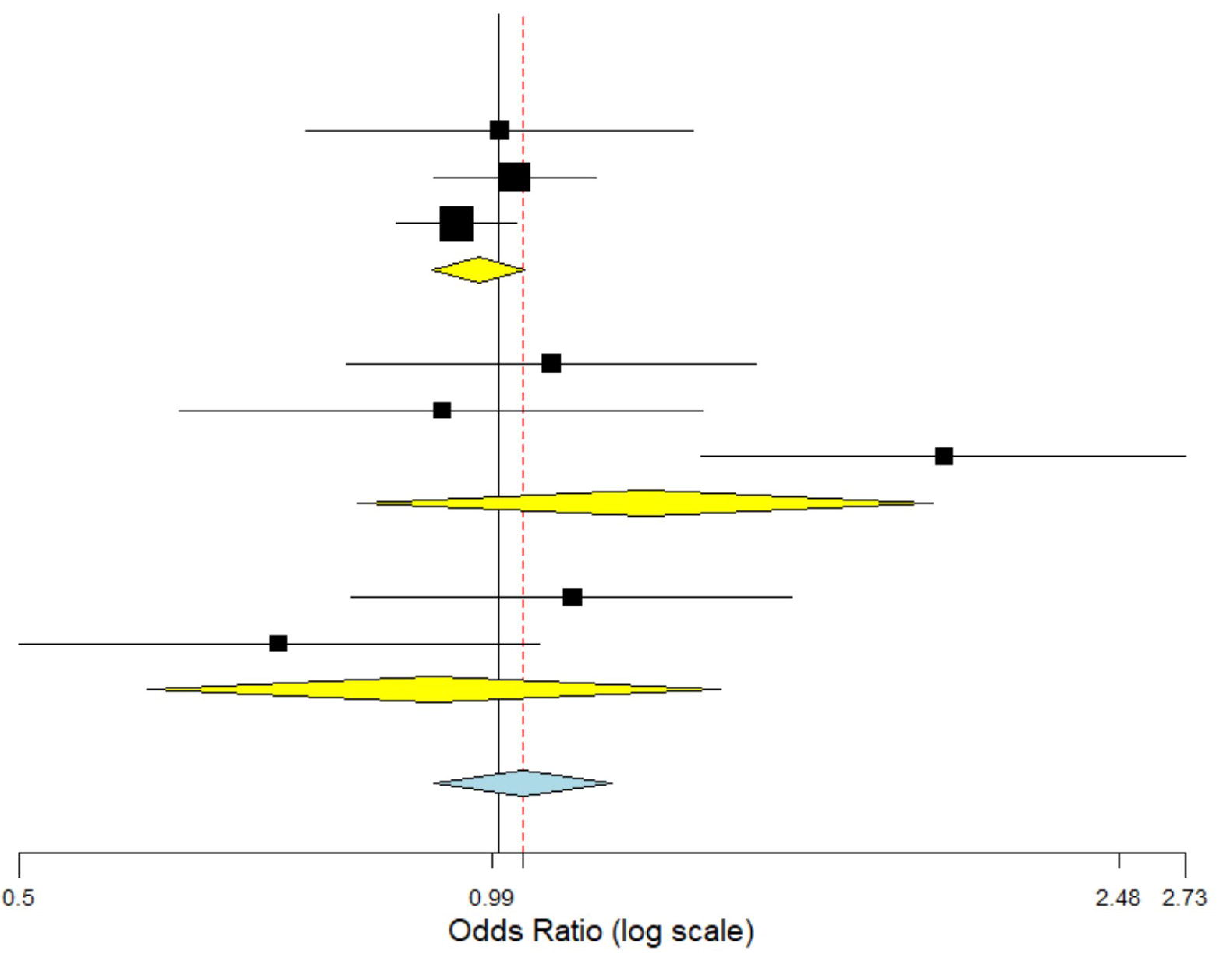


